\title{
Author Index Volume 6 (1998)
}

The issue number is given in front of the page numbers.

Ademovič, E., J.-C. Pesquet and G. Charbonneau, Wheezing Lung Sounds Analysis with adaptive local trigonometric transform

Ademovič, E., J.-C. Pesquet and G. Charbonneau, Time-scale segmentation of respiratory sounds

(1) $41-51$

Ademovič, E., see Pesu, L.

(1) $53-63$

(1) $65-74$

Badger, A.M., see Kapadia, R.D.

$(5,6) 361-372$

Barbaro, V., M. Grigioni, C. Daniele and G. D' Avenio, Principal stress analysis in LDA measurements of the flow field downstream of $19-\mathrm{mm}$ Sorin Bicarbon heart valve

(4) 259-270

Berler, A., see Pavlopoulos, S.

Bolander, M.E., see Ritman, E.L.

Bracale, M., see Formisano, E.

$(2,3) 101-110$

$(5,6) 403-412$

$(2,3) 111-123$

Cain, S.A., see Helm, B.A.

Charbonneau, G., see Ademovič, E.

Charbonneau, G., see Ademovič, E.

Cheetham, B.M.G., see Plante, F.

Cheetham, B.M.G., see Sun, X.

Cheetham, B.M.G., see Sun, X.Q.

Cloetens, P., see Peyrin, F.

Coatney, R.W., see Kapadia, R.D.

Crawford, C., see Stores, G.

Daniele, C., see Barbaro, V.

D'Avenio, G., see Barbaro, V.

Di Salle, F., see Formisano, E.

(2,3) $195-207$

(1) $41-51$

(1) $53-63$

(1) $23-32$

(1) $3-10$

(4) $275-283$

$(5,6) 391-401$

$(5,6) 361-372$

(4) $231-236$

(4) 259-270

(4) 259-270

$(2,3) 111-123$

Dodds, R.A., see Kapadia, R.D.

Dufresne, T., Segmentation techniques for analysis of bone by three-dimensional computed tomographic imaging

$(5,6) 361-372$

$(5,6) 351-359$

Earis, J.E., see Plante, F.

Earis, J.E., see Sun, X.

Earis, J.E., see Sun, X.Q.

Evans, K.G., see Sun, X.Q.

(1) $23-32$

(1) $3-10$

(4) $275-283$

(4) $275-283$

Felsenberg, D., see Gowin, W.

Fitzpatrick, L.A., see Ritman, E.L.

Formisano, E., A. Pepino, M. Bracale, F. Di Salle, C. Saulino and E. Marciano, Localisation and characterisation of auditory perception through Functional Magnetic Resonance Imaging 
Geiger, K., see Reisch, S.

(4) $245-257$

Gerber, S.C., see Müller, R.

$(5,6) 433-444$

Goldstein, S.A., see Zysset, P.K.

Gowen, M., see Kapadia, R.D.

Gowin, W., P.I. Saparin, J. Kurths and D. Felsenberg, Measures of complexity for cancellous bone

Grandori, F., see Tognola, G.

Grigioni, M., see Barbaro, V.

Guo, X.E., see Zysset, P.K.

Guttmann, J., see Reisch, S.

Haltsonen, S., see Sovijärvi, A.R.A.

Haltsonen, S., see Waris, M.

Haupt, D.L., see Kinney, J.H.

Häuselmann, H.J., see Laib, A.

$(5,6) 429-432$

$(5,6) 361-372$

$(5,6) 373-390$

$(2,3) 159-175$

(4) $259-270$

$(5,6) 429-432$

(4) $245-257$

(1) $11-22$

(1) $33-40$

$(5,6) 339-350$

$(5,6) 329-337$

$(5,6) 433-444$

(1) $65-74$

Helistö, P., see Pesu, L.

Helistö, P., see Sovijärvi, A.R.A.

Helistö, P., see Vanderschoot, J.

Helistö, P., see Waris, M.

Helm, B.A., I. Sayers, J. Swan, L.J.C. Smyth, S.A. Cain, M. Suter, D.C. Machado, A.C. Spivey and E.A. Padlan, Protein and cell engineering of components of the human immunoglobulin $\mathrm{E}$ receptor/effector system: applications for therapy and diagnosis

Hoffler, C.E., see Zysset, P.K.

Hwang, S.N., see Wehrli, F.W.

Jämsä, K. and T. Jämsä, Technology in neonatal intensive care - a study on parents' experiences

Jämsä, T., see Jämsä, K.

Kallio, K., see Sovijärvi, A.R.A.

Kapadia, R.D., G.B. Stroup, A.M. Badger, B. Koller, J.M. Levin, R.W. Coatney, R.A. Dodds, X. Liang, M.W. Lark and M. Gowen, Applications of micro-CT and MR microscopy to study pre-clinical models of osteoporosis and osteoarthritis

Katila, T., see Sovijärvi, A.R.A.

Kessler, H., see Plante, F.

Kinney, J.H., J.T. Ryaby, D.L. Haupt and N.E. Lane, Three-dimensional in vivo morphometry of trabecular bone in the OVX rat model of osteoporosis

Koller, B., see Kapadia, R.D.

Kothari, M., see Van Rietbergen, B.

Koutsouris, D., see Pavlopoulos, S.

Kowalczyk, L., see Skubiszak, L.

Kozinets, G., see Sakhno, L.

Kozińska, D., R. Tarnecki and K. Nowiński, Presentation of brain electrical activity distribution on its cortex surface derived from MR images

Kurths, J., see Gowin, W.

Kyriacou, E., see Pavlopoulos, S.

(1) $11-22$

(1) $81-89$

(1) $33-40$

$(2,3)$ 195-207

$(5,6) 429-432$

$(5,6) 307-320$

(4) $225-230$

(4) $225-230$

(1) $11-22$

$(5,6) 361-372$

(1) $11-22$

(1) $23-32$

$(5,6) 339-350$

$(5,6) 361-372$

$(5,6) 413-420$

$(2,3) 101-110$

$(2,3)$ 139-149

$(2,3)$ 125-130

$(2,3)$ 209-224

$(5,6) 373-390$

$(2,3) 101-110$

Laib, A., H.J. Häuselmann and P. Rüegsegger, In vivo high resolution 3D-QCT of the human forearm

Laib, A., see Ulrich, D.

$(5,6) 329-337$

$(5,6) 421-427$ 
Laib, A., see Van Rietbergen, B.

$(5,6) 413-420$

Landini, L., see Santarelli, M.F.

$(2,3) 151-157$

Lane, N.E., see Kinney, J.H.

Lark, M.W., see Kapadia, R.D.

$(5,6) 339-350$

$(5,6) 361-372$

Laval-Jeantet, A.M., see Peyrin, F.

Le Dour, O. and I. Norstedt, An opportunity for exploitation of research in biomedical engineering: the EC Life Sciences Demonstration Projects

$(5,6) 391-401$

Levin, J.M., see Kapadia, R.D.

Liang, X., see Kapadia, R.D.

Lipponen, P., see Sovijärvi, A.R.A.

Lipponen, P., see Vanderschoot, J.

Lossitskaya, V., see Sakhno, L.

Machado, D.C., see Helm, B.A.

Majumdar, S., A review of magnetic resonance (MR) imaging of trabecular bone microarchitecture: contribution to the prediction of biomechanical properties and fracture prevalence

Majumdar, S., see Van Rietbergen, B.

Malmberg, L.P., see Sovijärvi, A.R.A.

Marciano, E., see Formisano, E.

Maslenny, V., see Sakhno, L.

Melnikov, O.R., Effects of endogenous N-nitrosodiethylamine and blocking of its synthesis with ascorbic acid on the condition of the liver monooxygenase system

Moore, K.E., see Zysset, P.K.

Mosekilde, L., The effect of modelling and remodelling on human vertebral body architecture

Müller, R., S.C. Gerber and W.C. Hayes, Micro-compression: a novel technique for the nondestructive assessment of local bone failure

(4) $237-243$

$(5,6) 361-372$

$(5,6) 361-372$

(1) $11-22$

(1) $81-89$

$(2,3) 125-130$

$(2,3) 195-207$

$(5,6) 321-327$

$(5,6) 413-420$

(1) $11-22$

$(2,3) 111-123$

$(2,3) 125-130$

$(2,3) 131-137$

$(5,6) 429-432$

$(5,6) 287-297$

$(5,6) 433-444$

(1) $11-22$

Näveri, L., see Sovijärvi, A.R.A.

Newitt, D.C., see Van Rietbergen, B.

Nikolaev, V., see Sakhno, L.

Norstedt, I., see Le Dour, O.

Nowakowski, A., see Wtorek, J.

Nowiński, K., see Kozińska, D.

$(5,6) 413-420$

$(2,3) 125-130$

(4) 237-243

$(2,3) 177-193$

$(2,3)$ 209-224

Paajanen, E., see Sovijärvi, A.R.A.

Padlan, E.A., see Helm, B.A.

Pasquali, G., see Vannuccini, L.

(1) $11-22$

$(2,3) 195-207$

(1) $75-79$

Pavlopoulos, S., A. Berler, E. Kyriacou and D. Koutsouris, Design and development of a multimedia database for emergency telemedicine

Pekkanen, L., see Sovijärvi, A.R.A.

Pepino, A., see Formisano, E.

Pesquet, J.-C., see Ademovič, E.

Pesquet, J.-C., see Ademovič, E.

Pesquet, J.-C., see Pesu, L.

Pesu, L., P. Helistö, E. Ademovič, J.-C. Pesquet, A. Saarinen and A.R.A. Sovijärvi, Classification of respiratory sounds based on wavelet packet decomposition and learning vector quantization

Peyrin, F., M. Salome, P. Cloetens, A.M. Laval-Jeantet, E. Ritman and P. Rüegsegger, Micro-CT examinations of trabecular bone samples at different resolutions: 14, 7 and 2 micron level

$(2,3) 101-110$

(1) $11-22$

$(2,3) 111-123$

(1) $41-51$

(1) $53-63$

(1) $65-74$

(1) $65-74$

$(5,6) 391-401$ 
Piirilä, P., see Sovijärvi, A.R.A.

(1) $11-22$

Piirilä, P., see Vanderschoot, J.

(1) $81-89$

Pistoia, W., see Van Rietbergen, B.

Plante, F., H. Kessler, X.Q. Sun, B.M.G. Cheetham and J.E. Earis, Inverse filtering applied to upper airway sounds

Poliñski, A., see Wtorek, J.

Positano, V., see Santarelli, M.F.

Povstyanoy, N., see Sakhno, L.

$(5,6) 413-420$

(1) $23-32$

$(2,3) 177-193$

$(2,3) 151-157$

$(2,3) 125-130$

Ravazzani, P., see Tognola, G.

Reisch, S., M. Schneider, J. Timmer, K. Geiger and J. Guttmann, Evaluation of forced oscillation technique for early detection of airway obstruction in sleep apnea: a model study

Rietbergen, B., see Ulrich, D.

Ritman, E., see Peyrin, F.

Ritman, E.L., M.E. Bolander, L.A. Fitzpatrick and R.T. Turner, Micro-CT imaging of structureto-function relationship of bone microstructure and associated vascular involvement

$(2,3) 159-175$

(4) 245-257

$(5,6) 421-427$

$(5,6) 391-401$

$(5,6) 403-412$

Rossi, M. and L. Vannuccini, Placing crackles on the flow-volume plane: a study of the relationship between the time position, the flow and the volume

Rossi, M., see Vannuccini, L.

Rüegsegger, P., see Laib, A.

Rüegsegger, P., see Peyrin, F.

Rüegsegger, P., see Ulrich, D.

Rüegsegger, P., see Van Rietbergen, B.

Ryaby, J.T., see Kinney, J.H.

Saarinen, A., see Pesu, L.

Saarinen, A., see Sovijärvi, A.R.A.

Saarinen, A., see Waris, M.

Sakhno, L., V. Sarnatskaya, M. Zinovieva, L. Yushko, V. Maslenny, G. Kozinets, V. Lossitskaya, N. Povstyanoy and V. Nikolaev, Deliganded albumin as a liquid adsorbent in the treatment of burn toxemia

Salome, M., see Peyrin, F.

Santarelli, M.F., V. Positano and L. Landini, On-line 3D evaluation of left ventricular wall motion in magnetic resonance imaging

Saparin, P.I., see Gowin, W.

Sarnatskaya, V., see Sakhno, L.

Saulino, C., see Formisano, E.

Sayers, I., see Helm, B.A.

Schneider, M., see Reisch, S.

Schoenmakers, C., CE marking of medical devices

Selman, J., see Stores, G.

Skubiszak, L. and L. Kowalczyk, Computer system modelling muscle work

Smyth, L.J.C., see Helm, B.A.

Song, H.K., see Wehrli, F.W.

Sovijärvi, A.R.A., P. Helistö, L.P. Malmberg, K. Kallio, E. Paajanen, A. Saarinen, P. Lipponen, S. Haltsonen, L. Pekkanen, P. Piirilä, L. Näveri and T. Katila, A new versatile PC-based lung sound analyzer with automatic crackle analysis (HeLSA); repeatability of spectral parameters and sound amplitude in healthy subjects

Sovijärvi, A.R.A., see Pesu, L.

(1) $91-97$

(1) $75-79$

$(5,6) 329-337$

$(5,6) 391-401$

$(5,6) 421-427$

$(5,6) 413-420$

$(5,6) 339-350$

(1) $65-74$

(1) $11-22$

(1) $33-40$

$(2,3)$ 125-130

$(5,6) 391-401$

$(2,3) 151-157$

$(5,6) 373-390$

$(2,3)$ 125-130

$(2,3) 111-123$

$(2,3)$ 195-207

(4) 245-257

(4) $271-274$

(4) $231-236$

$(2,3)$ 139-149

$(2,3)$ 195-207

$(5,6)$ 307-320

(1) $11-22$

(1) $65-74$ 
Sovijärvi, A.R.A., see Vanderschoot, J.

(1) $81-89$

Sovijärvi, A.R.A., see Waris, M.

(1) $33-40$

Spivey, A.C., see Helm, B.A.

Stelter, J., see Wtorek, J.

Stores, G., C. Crawford, J. Selman and L. Wiggs, Home polysomnography norms for children Stroup, G.B., see Kapadia, R.D.

Sun, X., B.M.G. Cheetham and J.E. Earis, Real time analysis of lung sounds

Sun, X.Q., B.M.G. Cheetham, K.G. Evans and J.E. Earis, Estimation of analogue pre-filtering characteristics for CORSA standardisation

Sun, X.Q., see Plante, F.

Suter, M., see Helm, B.A.

Swan, J., see Helm, B.A.

$(2,3) 195-207$

$(2,3) 177-193$

(4) $231-236$

$(5,6) 361-372$

(1) $3-10$

(4) $275-283$

(1) $23-32$

$(2,3)$ 195-207

$(2,3)$ 195-207

Tarnecki, R., see Kozińska, D.

(2,3) 209-224

(4) $245-257$

Tognola, G., F. Grandori and P. Ravazzani, Time-frequency distribution methods for the analysis of click-evoked otoacoustic emissions

Turner, R.T., see Ritman, E.L.

$(2,3) 159-175$

$(5,6) 403-412$

Ulrich, D., B. Rietbergen, A. Laib and P. Rüegsegger, Mechanical analysis of bone and its microarchitecture based on in vivo voxel images

$(5,6) 421-427$

Vanderschoot, J., P. Helistö, P. Lipponen, P. Piirilä and A.R.A. Sovijärvi, Distribution of crackles on the flow-volume plane in different pulmonary diseases

Vannuccini, L., M. Rossi and G. Pasquali, A new method to detect crackles in respiratory sounds

Vannuccini, L., see Rossi, M.

Van Rietbergen, B., S. Majumdar, W. Pistoia, D.C. Newitt, M. Kothari, A. Laib and P. Rüegsegger, Assessment of cancellous bone mechanical properties from micro-FE models based on micro-CT, pQCT and MR images

(1) $81-89$

(1) $75-79$

(1) $91-97$

$(5,6) 413-420$

Waris, M., P. Helistö, S. Haltsonen, A. Saarinen and A.R.A. Sovijärvi, A new method for automatic wheeze detection

Wehrli, F.W., S.N. Hwang and H.K. Song, New architectural parameters derived from microMRI for the prediction of trabecular bone strength

Weinans, H., Is osteoporosis a matter of over-adaptation?

Wiggs, L., see Stores, G.

Wtorek, J., A. Poliñski, J. Stelter and A. Nowakowski, Cell for measurements of biological tissue complex conductivity

(1) $33-40$

$(5,6) 307-320$

$(5,6) 299-306$

(4) $231-236$

$(2,3) 177-193$

Yushko, L., see Sakhno, L.

$(2,3) 125-130$

Zinovieva, M., see Sakhno, L.

Zysset, P.K., X.E. Guo, C.E. Hoffler, K.E. Moore and S.A. Goldstein, Mechanical properties of human trabecular bone lamellae quantified by nanoindentation

$(2,3) 125-130$

$(5,6) 429-432$ 